\title{
АКТУАЛІЗАЦІЯ ФРАЗЕОЛОГІЧНИХ ОДИНИЦЬ У ДІАЛЕКТНОМУ ТЕКСТІ
}

\author{
НАТАЛІЯ КОВАЛЕНКО \\ Кам’янець-Подільський національний університет імені Івана Огієнка, \\ Кам’янець-Подільський — Україна \\ AKTUALIZACJA JEDNOSTEK FRAZEOLOGICZNYCH \\ W TEKŚCIE GWAROWYM \\ NATALIA KOWALENKO \\ Uniwersytet Narodowy im. Iwana Ohijenki w Kamieńcu Podolskim, \\ Kamieniec Podolski — Ukraina
}

STRESZCZENIE. W artykule opisano osobliwości użycia jednostek frazeologicznych (frazemów) we współczesnych tekstach gwarowych południowo-zachodniego narzecza. Analiza frazemiki na podstawie tekstów gwarowych może ujawnić zarówno nieutrwalone wcześniej jednostki, jak i realizację odrębnych frazemów w sytuacjach kontekstualnych z różnym znaczeniem, odmienną aktualizacją pojęciowego oraz emotywnego planu wyrażania. Szczególnie cennym wydaje się fakt, iż na tle frazeologii ujawnia się poziom kompetencji językowej nosiciela gwary.

\section{ACTUALIZATION OF PHRASEOLOGICAL UNITS IN DIALECT TEXT \\ NATALYA KOVALENKO \\ Ivan Ohiyenko Kamyanets-Podilskiy State University, Kamyanets-Podilskiy — Ukraine}

\begin{abstract}
The article describes the peculiarities of the use of phraseological units in modern dialectal texts of south-western dialect. In particular, the analysis of phraseological units on the basis of dialectal texts identifies either these units are of early non-fixed origin or are realized as phraseological units with different contextual meanings, as different actualizations of semantic and emotive schemes of the plane of expression. The noteworthy fact is that the level of language competence of a dialect speaker and the additional information about the speech reality are analyzed on the basis of phraseology.
\end{abstract}

$\Phi$ разеологізми українського діалектного мовлення стали об’єктом грунтовних досліджень останніх десятиліть. Емпіричну базу цього рівня мови поповнюють матеріали статей, дисертацій, монографій. Із-поміж публікацій, що фіксують сучасний стан фразеологічної системи діалектів кінця XX - початку XXI ст., найбільшу цінність мають українські діалектні словники: 1) західнополіських (Г. Аркушин ${ }^{1}$, 3. Мацюк ${ }^{2}$, середьополіських гові-

${ }^{1}$ Г. Л . А р куш и н, Сказав, як два зв'язав. Народні вислови та загадки із Західного Полісся $i$ західної частини Волині, Люблін-Луцьк 2003.

2 3. С. М а ц ю , Що сільие, то нове слівие: словник фразеологізмів Західного Полісся, Луцьк 2013. 
рок (Г. Доброльожа ${ }^{3}$ північноукраїнського наріччя; 2) східнослобожанських і степових (В. Ужченко та Д. Ужченко $)$, наддніпрянських говірок (В. Чабанен$\left.\kappa^{5}\right)$ південно-східного наріччя; 3) західноволинських (Г. Аркушин $\left.{ }^{6}\right)$, південноволинських (Н. Кірілкова $\left.{ }^{7}\right)$, західноподільських $\left(\right.$ Н. Коваленко $\left.{ }^{8}\right)$ південнозахідного наріччя української мови. Фраземіка лемківських говірок Східної Словаччини зафіксована в словнику Н. Вархол та А. Івченка9 можливості однієї говірки доводять праці Ю. Громика, М. Лесюка ${ }^{10,}{ }^{11}$. Лексикографічні праці підтверджують надзвичайно багатий фонд стійких сполучень слів, активне варіювання фразем в ареальній проекції на усіх рівнях.

Матеріали дисертацій, фразеологічних словників українських говірок фіксувалися від респондентів, як правило, за програмами-питальниками, але багатогранність і специфічність фраземи виявляється в непередбачуваності іiї семантики, функції, виражальних можливостей у зв'язному тексті. Напр., неможливо було би передбачити існування фраземи зі значенням 'з хати в хату':

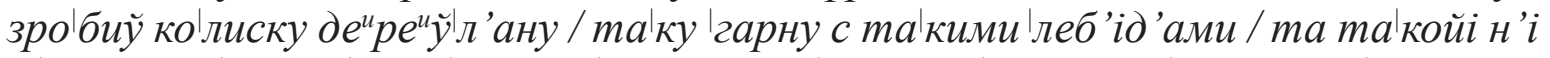

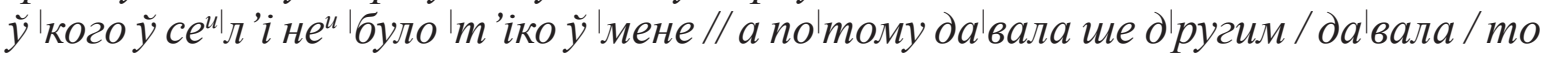

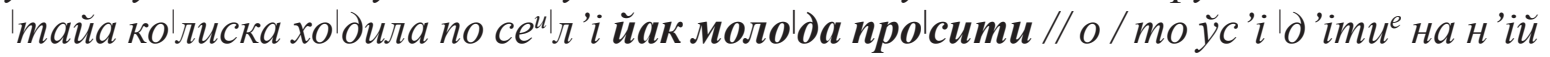
'виросли (с. Вишнівчик Чемеровецького р-ну Хмельницької обл.); 'запрошува-

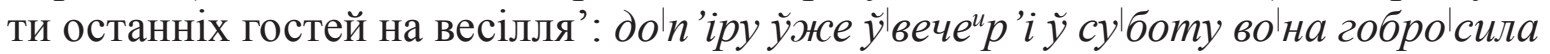

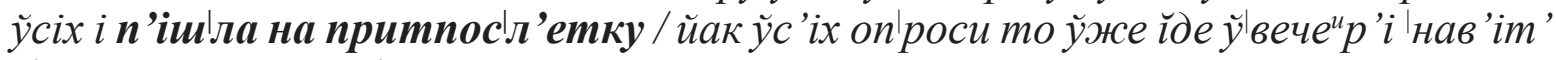
$i \mid n$ 'ізно цде до моло дого (с. Заставці Старосинявського р-ну Хмельницької обл.).

Бажаної інформативності можна досягти й завдяки використанню методу автокоментування, коли респондента просять прокоментувати значення лексеми (компонента фразеологізму), як правило, із затемненою семантикою. Така інформація $є$ надзвичайно показовою, тому що дані стосуються не тільки формальної структури, значення, ступеня яскравості конотативного складника, а й часової характеристики (колись чули, розказували старші люди, розказувала мама тощо). Інформатор, напр., дає таке пояснення лексеми гарма-

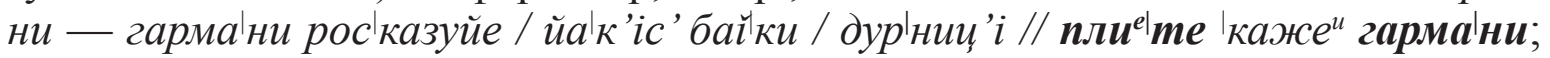
каня — 'кан'а 'видно п'ташка йа|кас'/ ие не иворона // 'кажеи сс 'іла йа'кас'|кан'а на дош'че (с. Станіславівка Віньковецького р-ну Хмельницької обл.); у подільських говірках не змогли пояснити значення слова трістя, але знають вираз

${ }^{3}$ Г. М. До б р ол ь ож а, Красне слово - як золотий ключ: Постійні народні порівняння в говірках Середнього Полісся та суміжних територій, Житомир 2003; Г. М. Доброльожа, Фразеологічний словник говірок Житомирщини, Житомир 2010.

${ }^{4}$ В. Д. Ужч енко, Д. В. Ужче н ко, Фразеологічний словник східнослобожанських $і$ степових говірок Донбасу, Луганськ 2013.

${ }^{5}$ В. А. Ч абан е н ко, Фразеологічний словник говірок Нижньої Наддніпрянщини, Запоріжжя 2001.

${ }^{6}$ Г. Л. А рк уш и н , Сказав, як два зв'язав. Народні вислови та загадки із Західного Полісся і західної частини Волині, Люблін-Луцьк 2003.

${ }^{7}$ Н. В. К ірі лко в а, Матеріали до фразеологічного словника південноволинських говірок, Остріг-Рівне 2011.

${ }^{8}$ Н. Д. Ко в ал енко, Слова з язика, як бджоли з вулика: матеріали до словника народних порівнянь подільських і волинських говірок Хмельниччини, Кам'янець-Подільський 2011.

${ }^{9}$ Н. В архол, А. Івч ен ко, Фразеологічний словник лемківських говірок Східної Словаччини, Пряшів 1990.

${ }_{10}$ М. Лесюк, Мовний світ сучасного галицького села (Ковалівка Коломийського району), Івано-Франківськ 2008.

${ }^{11}$ Ю. Громик, Фразеологізми середньополіської говірки села Липно Ківериівського району Волинської області, [в:] Волинь-Житомирщина: Історико-філологічний збірник з регіональних проблем, Житомир 2002, с. 152-170. 
зі значенням 'пропасти, зникнути': 'кажут n’iu|ла у $\boldsymbol{m} \boldsymbol{p}$ 'iclm'a. Словник буковинських говірок фіксує лексему з таким значенням: трі́стя - болото, трясовина ${ }^{12}$. Отже, в діалектному мовленні деякі лексеми збереглися лише у сталих виразах і втратилися в позафраземному вживанні.

Сьогодні, на думку П. Гриценка, для діалектологічних досліджень важливим $\epsilon$ „напрям не вибіркового (ілюстративного) чи репертуарно заданого добору й опису одиниць і явищ, а суцільного опрацювання значних масивів текстів (із посиленням уваги до ідіолекту, мовної особистості діалектоносія, до різноманітних комунікативних ситуацій, взаємодії вербальних засобів спілкування)"'13. Для того, щоб досягти докладності у вивченні говірки, говору тощо, чи окремих мовних явищ, треба поєднувати текстові фіксації матеріалу із записами за різноманітними програмами-питальниками.

Вивчення актуалізації фразеологічних одиниць проводилося переважно на матеріалі української літературної мови, за даними масиву діалектних текстів таких досліджень немає.

Джерельною базою для дослідження особливостей уживання фразеологічних одиниць слугували тексти, записані автором від носіїв подільських, волинських, наддністрянських і буковинських говірок південно-західного наріччя української мови впродовж 2000-2012 рр.

Аналіз матеріалу показав, що в текстах діалектного мовлення є специфічні риси, пов'язані з усною формою висловлення. У них можна спостерігати структурно-значеннєві риси фразеологічних одиниць, їх функціональні особливості, семантичну організацію, а особливо контекстуальні можливості. На підставі текстів виявляємо як нефіксовані раніше одиниці, так і реалізацію окремих фразем у контекстуальних ситуаціях із різним значення, різною актуалізацією смислового, емотивного плану вираження. Особливо цінним є те, що на тлі фразеології розкривається рівень мовної компетенції діалектоносія, додаткова інформація про реальність мовлення в просторі.

Носій говірки, мовець намагається чіткіше й повніше передати співрозмовнику зміст свого повідомлення, найтонші емоції та стани, дошукуючи слова, вдалі фразеологічні одиниці.

1. Виявляємо власне діалектні фраземи 3 компонентами-регіоналізмами, семантико-структурні моделі яких можуть мати загальноукраїнський тип: а ту'во лие ши / йа ли

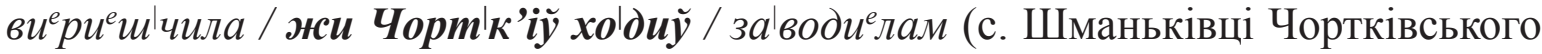

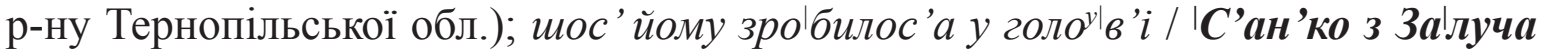
(с. Залуччя Чемеровецького р-ну Хмельницької обл.); за|ходит 'н 'іме ${ }^{u} u$ / йак в 'iн

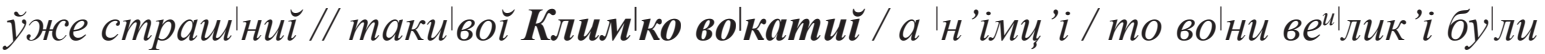
(с. Завалійки Волочиського району Хмельницької області).

2. Особливо цінним є поповнення емпіричної бази новими, незафіксованими в лексикографічних джерелах, фраземами: 'голодувати' - не $x o^{y \mid} m$ 'iлa

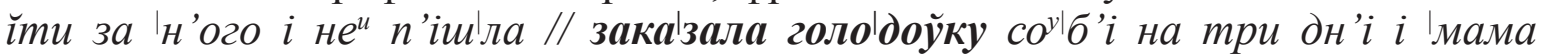
mо ${ }^{y \mid}$ ' $і$ поди'вилас'а шо так (с. Сахкамінь Кам'янець-Подільського р-ну Хмельницької обл.); 'забавлятися' - г'ратис'а 'тожи ни 'було чим / тий гл'а'д’iли

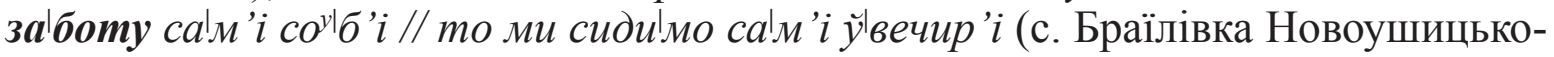
го р-ну Хмельницької обл.); 'швидко, абияк' - так 'перше

${ }^{12}$ Словник буковинських говірок, Чернівці 2005, с. 553.

${ }^{13}$ П. Гр и це н ко, Локалізми у структурі діалектної мови, [в:] „Jazykovedné štúdie”, XXVIII: Súradnice súčasnej slovanskej dialektológie, Bratislava 2010, c. 238. 
// а те пер уус'о Ігала драла / там 'дивис'а 'лопло ўже / там посунулос'а / тай так во'но йе (с. Слобідка-Рихтівська Кам'янець-Подільського р-ну Хмельниць-

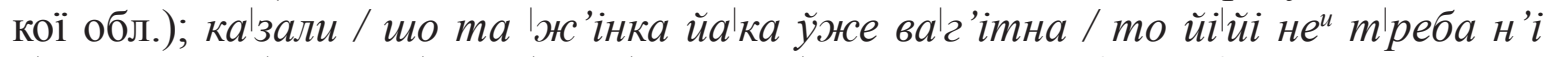

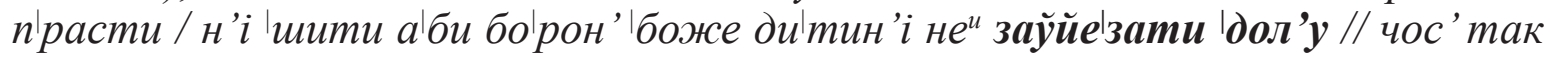

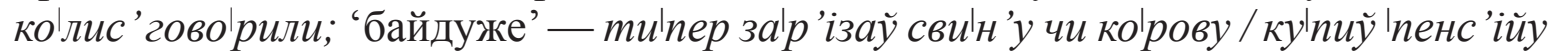

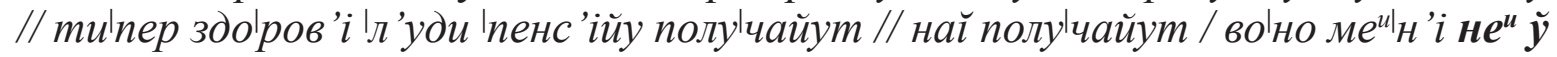
’мод’ (с. Лошківці Дунаєвецького р-ну Хмельницької обл.).

3. Вигукові фраземи виявляємо в полі дружньої побутової комунікації, коли

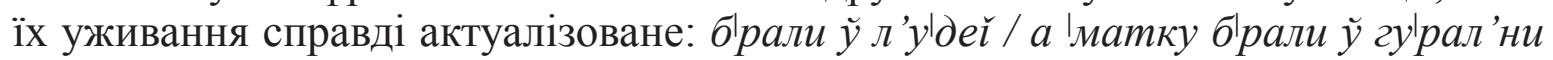

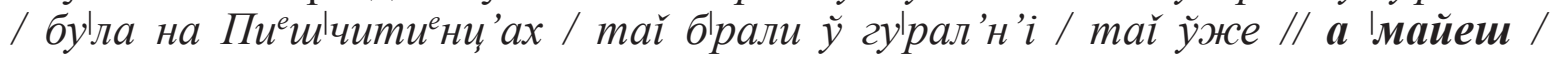

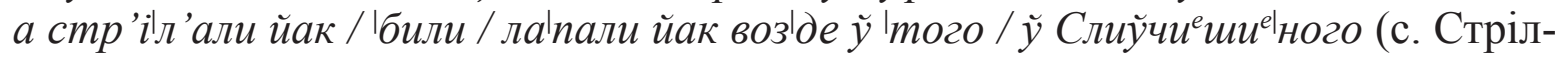
ківці Борщівського р-ну Тернопільської обл.); clm'iл'ко иче булло 'paдос'm'i / i скк'іл'ко було Ігордост'i / mо 'божи ти м’ї (с. Залуччя Чемеровецького р-ну

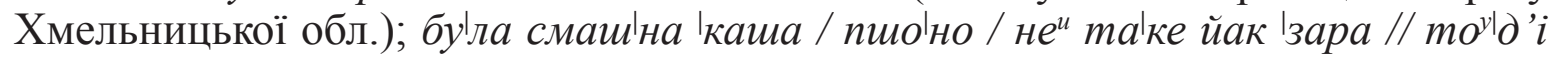
'каша 'була смаш'на / ио де / пшо'н'ана (с. Лошківці Дунаєвецького р-ну Хмельницької обл.); ходдила с ко сойу / ma|кий буў ко сар 'хот' ку'да (с. Сошне Ізя-

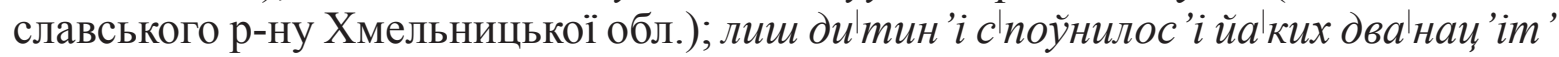
'рок'iў / то'то ууже буў та'кий пом'іч'ник n'id |хатоў / шо йа ти дам (с. Завалля Кам'янець-Подільського р-ну Хмельницької обл.). Зауважимо, що й у вигукових виразах можна виявляти мовні територіальні риси.

4. Та сама фразема в різних контекстуальних ситуаціях може мати різне значення й актуалізацію смислового, емотивного плану вираження: йа |памйатu

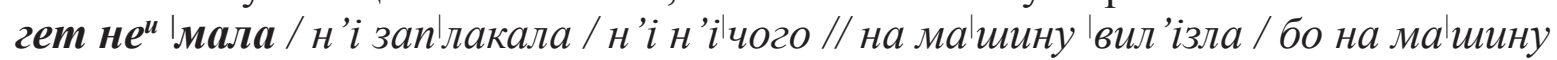
нас вига'н'ели 'розгубитися' (с. Бишки Козівського р-ну Тернопільської обл.); бо 'мамиен 'бат'ко маў пчоли / 'але йо го роскур|кулиели / 'вигнали йо'го с 'хати / але 'пот 'ім пома лен'ко / йак то 'кажут / даў бог / n'id|в'іуус'а на 'ноги / стаў зноўгосподаром / зноў роз'в'іў пч 'іл і так m'i n'чоли ве ків, стати заможним' (смт Теофіполь Хмельницької обл.); йа'ке ж те ' ’еuтво

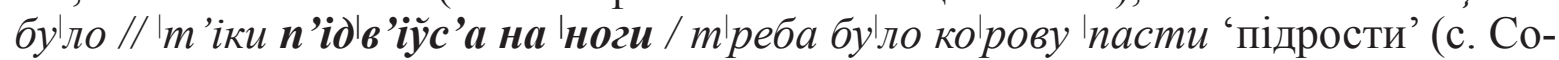

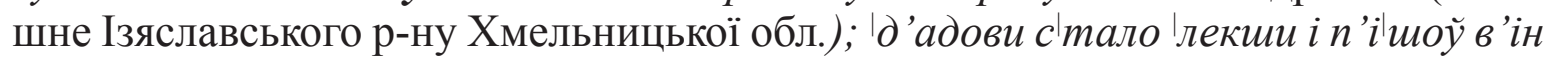

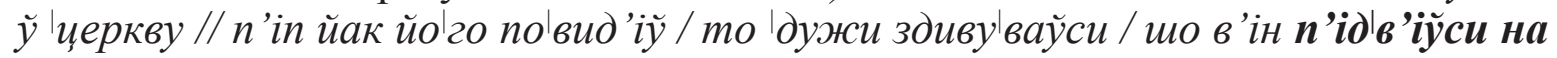
'ноги / бо буў ужже його 'виспов 'iдай 'видужати' (смт Мельниця-Подільська Борщівського р-ну Тернопільської обл.); $і$ ўже n'ідрос'ла либо|да / ma|ка зе $e^{u \mid л е н а ~}$

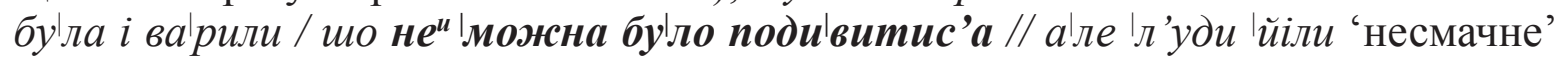
(с. Лошківці Дунаєвецького р-ну Хмельницької обл.).

5. В аналізованих текстах спостерігаємо переважне вживання фразем порівняльного типу, зокрема мовці намагаються образно передати відповідний

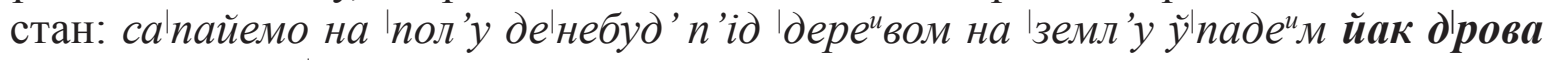
/ $i$ ўс'i nозасип|л'али (с. Стара Гута Новоушицького р-ну Хмельницької обл.); у кольгосп'і роббила на 'пол'y / $і$ лан'койу бу|ла і шо ти не хоч / бо 'ваша 'бапка пере $e^{u}{ }^{\prime}$ ва // а ти'пер ўже не $\left.\right|^{u}$ можу / ле ці Дунаєвецького р-ну Хмельницької обл.).

6. Непідготовленість та лінійність усного мовлення є причиною повторів як лексем, так і фразеологізмів. Трапляються висловлювання, де реципієнт не може підібрати заміни виразу, а, отже, не може уникнути повтору, напр.: колли бу

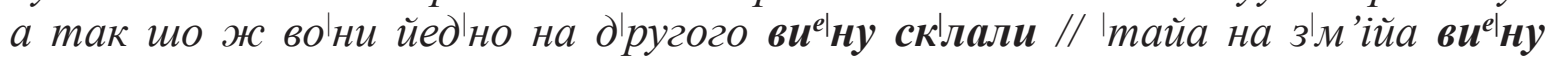
склала / а той на ১ж 'інку склай (с. Синяківці Дунаєвецького р-ну Хмельницької обл.). Повтори фразем трапляються і з метою увиразнення: ГаІлина Сел 'ilван 'iўна 


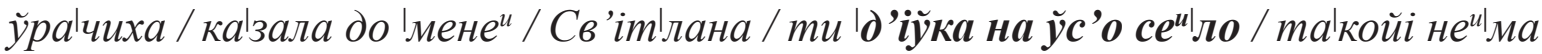
// 'коси у 'мене бу бли 'дуже ве

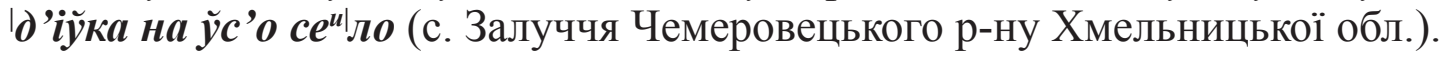

Повторне вживання виразу, але в другій половині фрази зі зворотним порядком слів (явище хіазму ${ }^{14}$ ) в деяких текстах може мати стилістичне наван-

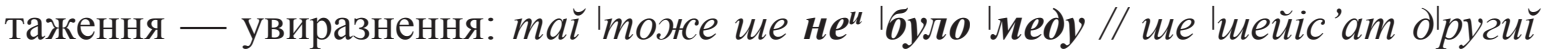
/ mретиц р’ік / 'меду не и Ібуло / 'тоже ше 'було 'm'ашко (с. Лошківці Дунаєвецького р-ну Хмельницької обл.). Повторюватися можуть фраземи з варіаціями компонентів, що не впливають на зміст, а, на нашу думку, свідчать про мовну компетентність, словесну майстерність інформатора: йак'що 'д 'іўка бу'ла та ка при сывойім ха|рактер'i / а йа вам с'кажу / шо ко лис' та|ке 'було 'дуже

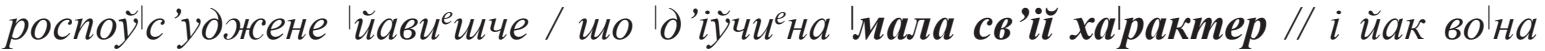

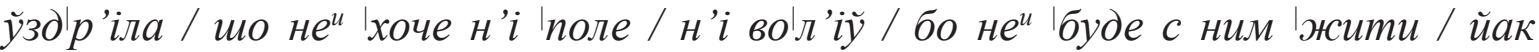
тие и'нула з'верху руш'ник / а з|низу гар буз (с. Жизномир Бучацького р-ну Тернопільської обл.); 'д 'іўчина n'iшыла до 'моста тай перетво рилас'а на в'іў и'у // ко ли во ни по бачили / йіх охо|пиў страх // по чаў страх на|ходити на ўс' о се (с. Кульчіївці Кам'янець-Подільського р-ну Хмельницької обл.).

7. В окремих випадках мовець уживає підряд два сталих вирази з однаковою семантикою, без ознак явища градації, що підтверджує мовленнєву вправ-

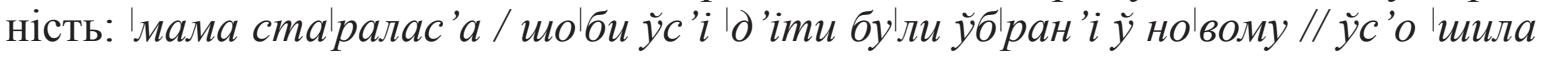
нам зо с'татного / готу'вала ўс'о // уббирала так йак Імайе 'бути / йак Бог прика зау / бо то ўс'і йили до циеркви (с. Завалля Кам'янець-Подільського р-ну); 'мона шо хоч ку|пити за гlрош'i // Iтата й 'мами с 'того с'в'іта не |купиш // ми

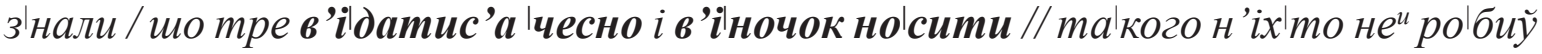
йак ти'пер (с. Лошківці Дунаєвецького р-ну Хмельницької обл.).

8. Нагромадження кількох фразем теж можливе в мовленнєвих ситуаціях, коли ці одиниці об'єктивно необхідні: йі йі назие вали пок'риткоў / то во на

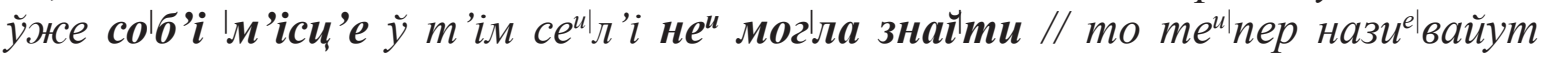
по 'p'ізному / то 'мама одие|начка / то ше шос' та|ке / а ко|лис' то нен бу'ло i'накшого с'пособу // та л'удина ўже 'була гет пропашча / ўже во'на се не

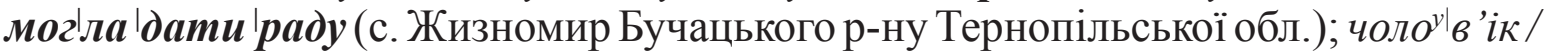

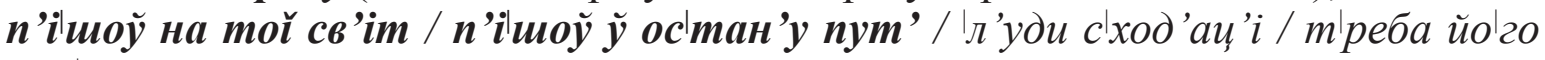
про'вести (с. Радковиця Городоцького р-ну Хмельницької обл.).

9. Найвищий вияв гострих переживань (як правило, негативних, пов'язаних із трагічними подіями) в розповідях мовці передають частовживаними фраземами: бомббли / та|ке бу|ло Ігоре / не оку'в 'ірувалис' / до йіхали до Чуд|нова (с. Котелянка Полонського р-ну Хмельницької обл.); а Іголод / Іголод у 'сорок 'с 'ом'ім 'рои'і ни дай бог н'i|кому ска'зати / $\boldsymbol{i}$ ни 'мала ди'тину то да вали че рпаччок 'того / во ди з уггир ком / у колгосп'i (с. Хребтіїв Новоушицького р-ну Хмельницької обл.).

10. Жива внутрішня форма, гіперболізація, що виявляються у фразеозначенні, притаманні виразам із підсилювальною часткою аж⿻ у текстах усіх до-

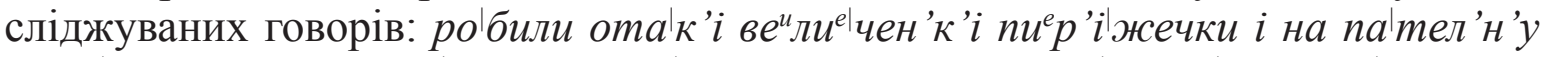
/ вобжсарили чи на воІл'їи'i чи у 'жиров'i / то ўже йа'к'i були смачнен'к'i / шо аж йази'ка з'іш 'разом з 'ними 'дуже смачні' (ст. Дунаївці Хмельницької обл.); 'але за'то та койба। са та|ка 'була / шо ажс ппл'чики об|лижеш (с. Жизномир Бучацького р-ну Тернопільської обл.); і ото зваримо пмона / посммачимо /

\footnotetext{
${ }^{14}$ Літературознавча енциклопедія в 2 m., автор-укл. Ю. Ковалі в, Київ 2007, т. 2, с. 557.
} 


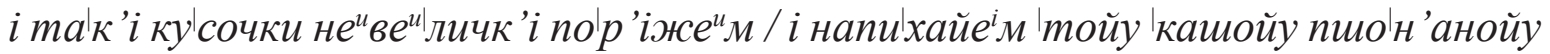
/ i вари'мо // то звалис'а к'л'оцки / о / йімо / ажс за вухами тр'ішичи' (с. Лепесівка Білогірського р-ну Хмельницької обл.).

11. У сучасних діалектних текстах поширеним $є$ вживання фраземи з таким розшифруванням, поясненням їі значення: се з'начило шо 'живо у 'Кас'i буде

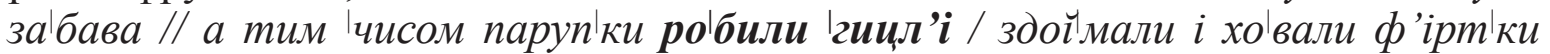
(с. Блищанка Заліщицького р-ну Тернопільської обл.); зас'ватайуm 'd’ ’ўчину / i назначчайут / у нас ко лис' робили 'куолку // так називалос'е та|ке бу|ло c'ватан'e (с. Ставки Заліщицького р-ну Тернопільської обл.); 'перше були

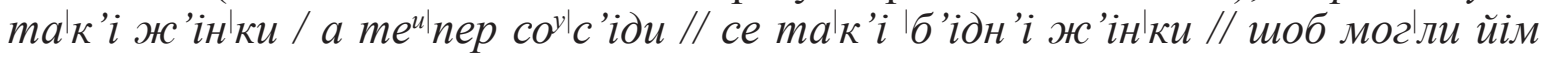
шос' 'дати / шо ўже во'на при|ходе а да'вали 'хусточку / чи сn'id'ничку (с. Почапинці Чемеровецького р-ну Хмель-

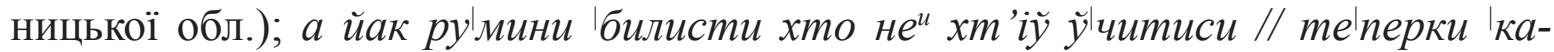

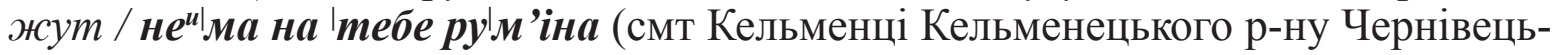
кої обл.). Зауважимо, що мовці пояснюють зацікавленому співбесіднику значення обрядових фразем, розуміючи втрату знань про обрядодійства, а відповідно й певних номінацій.

12. Для того, щоб конкретизувати, уточнити значення вжитої лексеми,

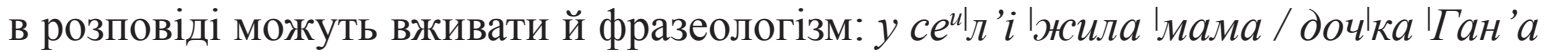

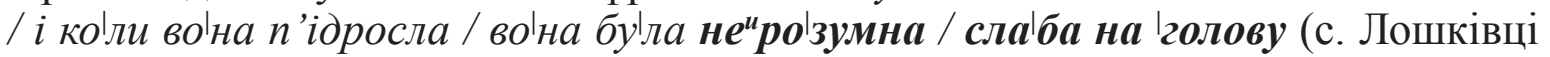
Дунаєвецького р-ну Хмельницької обл.); то 'була \пара на|в'іки / в’іd по и'етку до к'iн'и'e / а не то шо Ізараз (с. Жизномир Бучацького р-ну Тернопільської обл); заўж ди штыритали / шо во'на голод|ранка / шо во на Ігола 'боса приейыла /

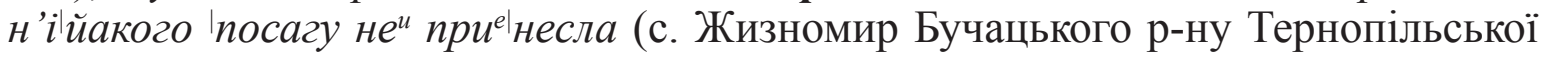
обл.). Протилежне явище, коли вживають фразелогізм, а далі лексеми з таким самим значенням, надає висловленню інтонації „стишення”, завершеності пе-

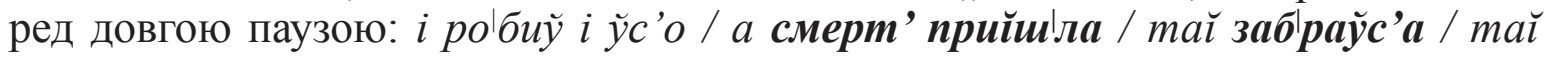

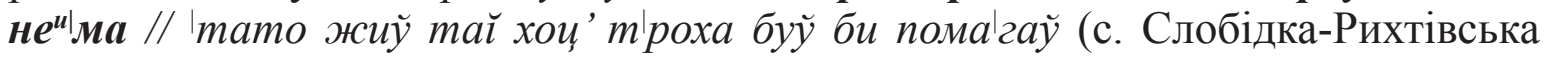
Кам'янець-Подільського району Хмельницької обл.).

13. Явище висхідної градації на рівні лексема-фразема теж досить поширене в усному мовленні: йа получчайу так 'само m'риста руб|л'ї̆ / йак 'тайа

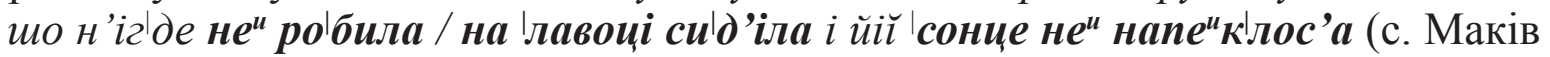
Дунаєвецького р-ну Хмельницької обл.); хл’іб получчайец'а у'кусний / 'добри ег̌ /

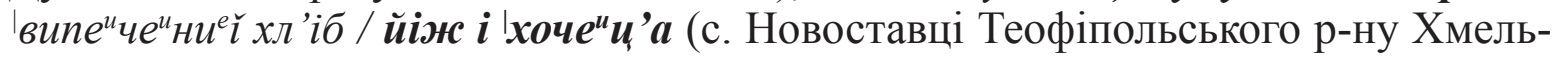

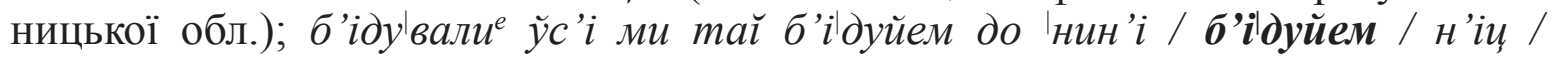

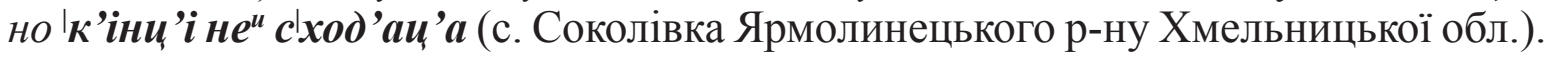

14. Для детального вивчення говірок важливими будуть дані про вживання діалектизмів у складі фразем: тай ко лис' / йак не йе / бу|ло баһато 'л 'уд 'ам 'лекше бу|ло // ууже ўс'о / йлло на 'танче / ўже 'л'уди ўс'о 'мали (с. Ставки За-

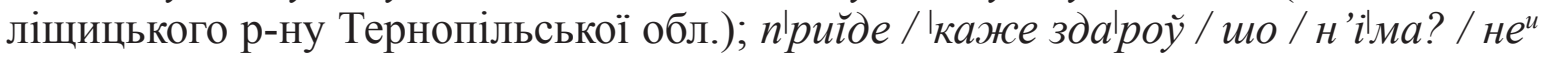

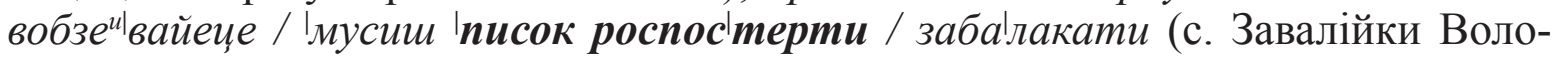
чиського району Хмельницької обл.). Актуальним є вирішення проблемних питань про просторове буття фразеологізму й власне його компонентів, наявність ареальних кореляцій.

Отже, тексти говіркового мовлення є невичерпним матеріалом для досліджень усіх мовних рівнів. Саме на такому матеріалі можна простежити універсальність явищ фразеовживання, коли максимально не навантажена в мові одиниця в комунікації стає центральною. Особливо яскраво це спостерігаємо в момент живого спілкування, коли до інформації, повідомлення долучається 
респондент, і передача експресії перетягується на фразеологічну одиницю, інтонацію, тон, висоту, темп, сегментні та суперсегментні фонетичні, акцентноритмічні характеристики, що є важливими в усній комунікації, а відповідно, й у характеристиці усного мовлення.

Системне дослідження фразем і їх компонентів на матеріалах текстів дає можливість простежити аналогійні явища в різних ареалах однієї мови, або на міжмовному просторі; виявити як нефіксовані раніше стійкі сполучення слів, так і відсутність очікуваних їх компонентів, стійкість різних діалектних явищ; описати ідіолектну специфіку. 